\title{
Slowing down too fast
}

\author{
U. C. Nguyên · P. M. J. C. Kuijpers
}

Accepted: 9 November 2020 / Published online: 1 December 2020

(C) The Author(s) 2020

A 77-year-old man was hospitalised for non-ST-elevation myocardial infarction. His telemetry recording showed atrial fibrillation with a fast ventricular rate (Fig. 1a). The patient was normotensive and was treated with metoprolol tartrate $25 \mathrm{mg}$ three times daily to control the heart rate and angina. Briefly after administration of the first metoprolol dose, he became hypotensive (RR $80 / 60 \mathrm{mmHg}$ ) and bradycardic (Fig. 1b). He was placed in Trendelenburg position, after which his symptoms decreased substantially. Although his blood pressure normalised after metoprolol discontinuation, the bradycardia persisted for over two days.

Cytochrome P450 (CYP) polymorphism analyses were carried out and revealed the patient was a very poor $\left({ }^{*} 4 /{ }^{*} 4\right)$ metaboliser of CYP2D6 and CYP2C9; CYP2C19 function was diminished. The symptomatic hypotension and bradycardia after metoprolol were attributed to the CYP2D6 polymorphism [1, 2]. Genetic polymorphism testing of CYP enzymes may therefore be considered, or should even be advised, in patients who demonstrate strong side effects to beta-blockers and in patients with polypharmacy.

Conflict of interest U.C. Nguyên and P.M.J.C. Kuijpers declare that they have no competing interests.
Open Access This article is licensed under a Creative Commons Attribution 4.0 International License, which permits use, sharing, adaptation, distribution and reproduction in any medium or format, as long as you give appropriate credit to the original author(s) and the source, provide a link to the Creative Commons licence, and indicate if changes were made. The images or other third party material in this article are included in the article's Creative Commons licence, unless indicated otherwise in a credit line to the material. If material is not included in the article's Creative Commons licence and your intended use is not permitted by statutory regulation or exceeds the permitted use, you will need to obtain permission directly from the copyright holder. To view a copy of this licence, visit http://creativecommons.org/licenses/by/4.0/.

\section{References}

1. Bijl MJ, Visser LE, van Schaik RH, et al. Genetic variation in the CYP2D6 gene is associated with a lower heart rate and blood pressure in beta-blocker users. Clin Pharmacol Ther. 2009;85:45-50.

2. Wijnen PA, Op den Buijsch RA, Drent M, et al. Review article: The prevalence and clinical relevance of cytochrome P450 polymorphisms. Aliment Pharmacol Ther. 2007;26(Suppl 2):211-9.
U. C. Nguyên ( $₫)$ · P. M. J. C. Kuijpers

Department of Cardiology, Maastricht University Medical

Center, Maastricht, The Netherlands

u.nguyen@maastrichtuniversity.nl 


\section{Heart Beat}

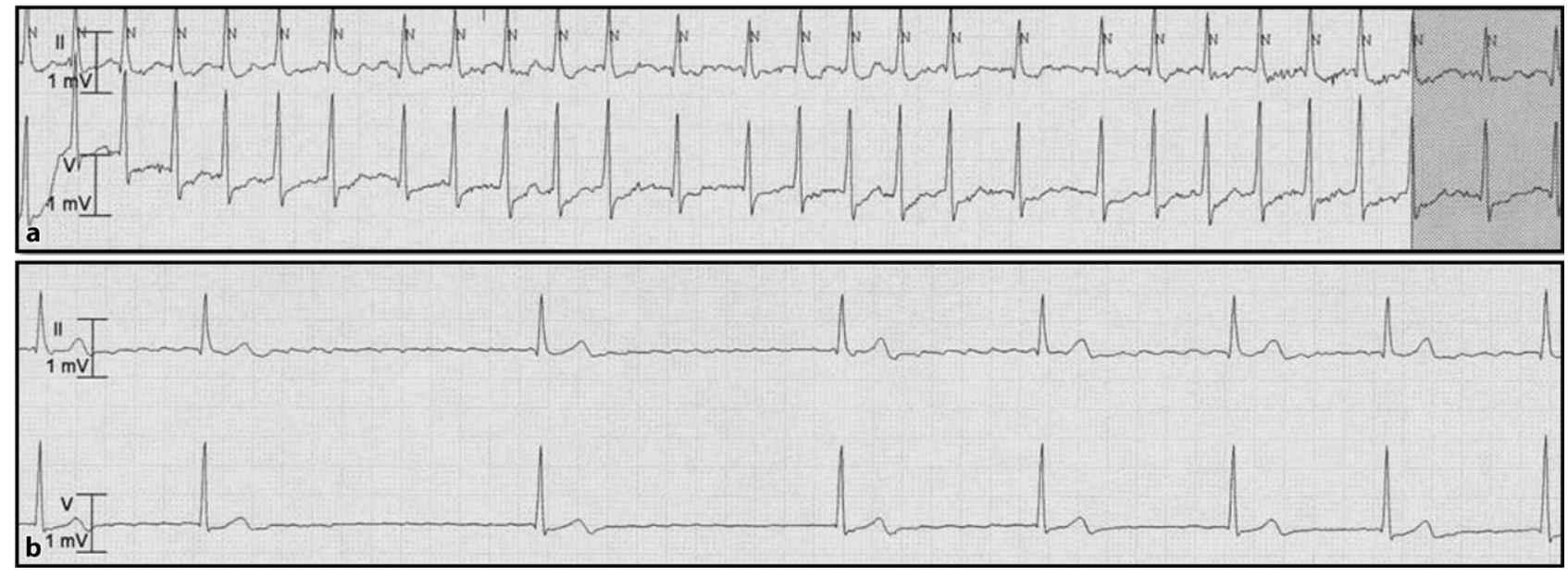

Fig. 1 Telemetric recordings during hospitalisation. a Atrial fibrillation with a fast ventricular rate. b Bradycardic episode after administration of metoprolol 